\title{
The Governance of Fair Trade Social Enterprises in Belgium
}

\author{
Benjamin HUYBRECHTS \\ Centre d'Economie Sociale \\ HEC - Liège Management School \\ University of Liège \\ b.huybrechts@ulg.ac.be
}

Key words: $\quad$ Fair Trade, Governance, Board of directors, Stakeholder involvement, Belgium

\begin{abstract}
$\underline{\text { Abstract }}$
Purpose - This article addresses the governance of "Fair Trade Social Enterprises" (FTSEs), i.e., the organisations exclusively dedicated to the import, distribution and/or labelling of fairly traded products. The aims are (1) to describe and categorise the types of persons and stakeholder groups represented in FTSEs' governance structures and (2) to look at the link between stakeholder involvement and other organisational features such as resources, goals and activities.

Design/methodology/approach - These questions are investigated through a qualitative field study based on face-to-face interviews with the managers of 15 Belgian FTSEs.

Findings - I distinguish three governance models each entailing different governance paradigms: the managerial model, the volunteer-based model and the multi-stakeholder model. In the three governance models, it is possible to link, to a certain extent, the composition of the governance structures, the access to resources and the goal priorities regarding the different dimensions of the FT activity. In brief, governance appears as an organisational entry revealing much information about the vision and the strategy of the FTSEs.

Research limitations/implications - This study is limited to Belgian FTSEs and must be considered as one of the first attempts in characterising the specific features and challenges of organisational governance in the FT context. International comparative studies exploring FTSE's governance in a more longitudinal perspective, combining the standpoints of diverse organisational actors, would be most welcome in the future.

Originality/value - As this article shows, the multidimensional nature of FT and the coexistence of different types of FTSEs in the same country make this a very interesting field to investigate the challenges of governance in social enterprises. Social enterprises and those researching them should pay more attention to the importance of adopting and conceiving governance schemes that are adapted to their multiple missions and enable the access to multiple resources.
\end{abstract}




\section{The Governance of Fair Trade Social Enterprises in Belgium}

\section{Introduction}

Fair Trade (FT) is expanding rapidly. Together with a dramatic boom in the sales of FT products ${ }^{1}$-as a consequence of their distribution in mainstream channels-, public awareness and attention from the academic world have recently increased (Moore, 2004; Nicholls \& Opal, 2005). In the North ${ }^{2}$, there have been global descriptions of the different networks and tendencies within the FT movement. Few studies, however, deal with how individual organisations are managed and governed (Davies \& Crane, 2003). Focusing on Fair Trade Social Enterprises (FTSEs) fully engaged in this activity ${ }^{3}$, my purpose is to open the "black box" of FT governance at the organisational level. The specific goals of this article are (1) to categorise FTSEs based on the types of stakeholders involved in their governance and (2) to explore how the differences in terms of governance can be linked to differences in resources, goals and activities. After the introduction, I summarise some theoretical elements about the governance of social enterprises. I then recall the fundamentals of FT, define what I mean by "FTSEs" and explain the methodology (part 3). Part 4 presents the main findings and their discussion, before concluding with part 5.

\section{Governance and stakeholders in social enterprises}

\subsection{Specific features and paradigms of governance in social enterprises}

Governance is a notion that can be used with very different meanings and on different levels of analysis (Cornforth, 2003). While issues of "corporate governance" have been widely discussed in the business world, there is a clear research gap concerning alternative organisations such as social enterprises. Yet, the specific features of these organisations (social mission, citizen involvement, participatory goals etc.) bring a number of specific and crucial governance challenges (Mason, 2009). Reviewing and applying the literature on Boards to nonprofit (charity) and cooperative social enterprises, Cornforth $(2003$; 2004) identifies six paradigms through which governance can be examined.

\section{- Agency theory-a compliance model}

Agency theory considers that the main function of governance structures is to control management, and to ensure compliance of managers with the shareholders' interests. Several authors suggest that agency theory is difficult to apply in all types of organisations, particularly in non-investor-owned forms such as charities, because of the ambiguity over who the principals or owners are (Cornforth, 2003). Yet, in any type of organisational form, even in charities (Labie, 2005), an agency perspective may be useful when we look at the governance structures as "guardians" of the organisational missions. Members of these structures should thus represent the owners and be able to control that the managers effectively pursue these missions.

\section{- Stewardship theory-a partnership model}


Stewardship theory has an opposite, non-opportunistic view on managers, who are seen as the "stewards" of the organisation's resources. The manager(s) and the governance structures are thus viewed as partners. The main function of governance is to increase organisational performance. The Board has a strategic function of implementing the mission. Its members should thus be selected on the basis of their expertise.

\section{- Resource dependency theory-a co-optation model}

In a resource dependency perspective (Pfeffer \& Salancik, 1978), the governance structures are located at the interface between the organisation and its environment. They thus constitute a means to reduce uncertainty by establishing linkages with other organisations and stakeholders so as to capture and secure resources (role of "boundary-spanning"). Members of the governance structures should be selected on the basis of their links with and knowledge of other organisations, allowing the organisation to gain a facilitated access to the resources crucial for its development.

\section{- A democratic perspective}

In such a perspective, governance structures should be elected by and represent the membership. Representation is the main role and members should be elected on the basis of their representative function rather than their expertise. This governance tradition is particularly strong in cooperatives and in volunteer-based charities (Labie, 2005).

\section{- A stakeholder perspective}

According to the stakeholder perspective, organisations have a responsibility toward various stakeholders concerned by their activity (Donaldson \& Preston, 1995; Freeman, 1984). The governance structures may thus be a place through which stakeholders are represented and have an influence on organisations. "By incorporating different stakeholders on boards, it is expected that organisations will be more likely to respond to broader social interests than the narrow interests of one group. This leads to a political role for boards negotiating and resolving the potential conflicting interests of different stakeholder groups in order to determine the objectives of the organisation and set policy" (Cornforth, 2003, 9). Mason (2009:218) suggests that the stakeholder model is rather evident in social enterprises, in the sense that "such organisations already recognize diverse stakeholder groups that likely do not benefit from its performance as corporate shareholders do".

\section{- Managerial hegemony theory-a 'rubber stamp' model}

Managerial hegemony theory is based on the thesis of Berle and Means (1932), that control is no longer exerted by the owners but rather by the managers. In this perspective, governance structures, particularly the Board, may be seen as "rubber stamps" for managers, providing legitimacy to their actions. Such a vision of governance is likely to be the most adequate when managers are in a powerful situation (typically when they have been holding their function for a 
long time), while members of the governance structures have only limited time and access to information.

Cornforth calls for a multi-paradigm approach, in which each paradigm brings a particular insight to the understanding of governance. Mason (2009) suggests that the stewardship and the stakeholder models have been dominating the literature on the governance of nonprofit organisations and social enterprises, although they both have a limited understanding of the governance dynamics. According to Cornforth, the combination of different paradigms is useful to highlight the paradoxes and tensions in governance. For instance, a typical source of tension lies between representative (democracy, stakeholder-based) and professional (stewardship, agency) governance. This article precisely aims to explore the governance logics and tensions that can be observed in FTSEs, without choosing one paradigm a priori.

\section{Field: Fair Trade and FTSEs in Belgium}

\subsection{Fair Trade}

The definition that gathers most agreement and is most widely used by field actors and academics (Moore, 2004) is the $\mathrm{FINE}^{4}$ definition:

Fair Trade is a trading partnership, based on dialogue, transparency and respect, that seeks greater equity in international trade. It contributes to sustainable development by offering better trading conditions to, and securing the rights of marginalised producers and workers especially in the South. Fair Trade organisations (backed by consumers) are engaged actively in supporting producers, awareness raising and in campaigning for changes in the rules and practice of conventional international trade.

It appears from this definition and from the sector's observation that FT is a highly multidimensional concept. From a theoretical point of view, FT combines dimensions that could be grouped under three categories:

- Trade: This includes all the market activities (import, transformation, distribution) similar to any trading initiative. Albeit "fair", FTSEs are running trade and using market mechanisms (Nicholls \& Opal, 2005). The positioning of trade in the strategy of FTSEs, however, can vary from a means to a goal on its own (Gendron, 2004).

- Fairness: FT pretends to conduct trade under "fair" conditions. These conditions constitute the core of the FT concept: fair price, social premium, pre-financing, provision of market access and long-term relationship (Moore, 2004; Nicholls \& Opal, 2005; Raynolds \& Wilkinson, 2007). These different tools are supposed to guide the trading relationship towards an effective socio-economic development for the producers in the South. This "bundle of fair characteristics" constitutes a specific-albeit invisible-attribute of FT products, differentiating them from non-FT products (Becchetti \& Rosati, 2005; Wilkinson, 2007).

- Education, regulation and advocacy: At the origins of FT, there is the intent of creating a new regulation framework for commercial exchanges. To that end, some FTSEs are active 
in advocacy through lobbying public authorities and denunciating unethical trading practices. International FT networks such as IFAT ${ }^{5}, \mathrm{FLO}^{6}$ or EFTA ${ }^{7}$ also carry out such advocacy role. Some FTSEs, mainly the pioneer ones, also run education campaigns directed to the consumers. These campaigns are intended to promote FT and to educate citizens towards consumption habits that are more respectful for the environment and the people.

These dimensions are, of course, interrelated and sometimes undistinguishable in practice (Wilkinson, 2007). For instance, presence on a trade fair can have both trading and education purposes. More fundamentally, the partnership with producer groups has both commercial and fairness purposes, trade being considered as one of the means to achieve development. Yet, it is important to keep in mind the multidimensional nature of the FT activity to better understand the differences among FTSES-including their governance models.

\subsection{FTSEs}

Originally, pioneer FTSEs were referred to as "alternative trading organisations", "a name stemming from the early days of Fair Trade where 'fair' seemed too weak a description of the vision that these companies had" (Moore, 2004:76). This term, however, is less and less used, simply because the term "alternative trade" has been replaced by that of "fair trade". WFTO defines "fair trade organisations" as "organizations directly engaged in Fair Trade through their trading activity". ${ }^{8}$ Different names have been used: "Fair Trade companies" (Davies \& Crane, 2003), "Fair Trade businesses" (Reed et al., forthcoming), "Fair Trade organisations" (Krier, 2005; Moore et al., forthcoming), etc. Organisations that have FT as the core of their activity can easily be described as social enterprises, thereby leading to the name "Fair Trade Social Enterprises". Despite the various definitions and theoretical approaches to social enterprise (Defourny \& Nyssens, 2008; Martin \& Osberg, 2007; Peattie \& Morley, 2008), FT organisations are regularly taken as examples of social enterprises (Doherty \& Tranchell, 2007; Huybrechts \& Defourny, 2008), with FT defined as a typical initiative of social entrepreneurship (Hervieux, 2008; Nicholls, 2006). Indeed, the social enterprise approach fits well to the combination of economic activity and social mission, the social innovation dynamics and the market resources that characterize FT organisations (Huybrechts \& Defourny, 2008). The diverse approaches to social enterprise are useful to describe the different types of FTSEs, from the volunteer-based charity to the managerial business.

\subsection{Field and methodology: Belgian FTSEs}

Belgium has a long FT history since the 1960s, with Oxfam as the pioneer and still leading FTSE (Krier, 2005). In the latest years, new organisations have emerged in the sector and a lot of companies are now active in the import, transformation and distribution of FT products. Even if FT in Belgium does not reach the market size and growth of champions such as Switzerland and the United Kingdom, it is among the most dynamic countries in Europe in terms of pro capita consumption and public awareness. ${ }^{9}$ What is particularly striking, however, compared to countries such as Italy (Viganò et al., 2008), is the very diversified organisational landscape of FTSEs in Belgium (Huybrechts, 2009). Such diversity also applies to governance models, which 
makes the Belgian landscape particularly interesting to examine various types of governance models for social enterprises. As there has been little research on FT in Belgium at this date, this article enables to provide a national analysis which adds to already known cases such as France (Diaz Pedregal, 2007) and the UK (Doherty \& Tranchell, 2007; Nicholls, forthcoming; Tallontire, 2000), and which uses the little examined lens of intra-organisational governance to enrich our understanding of this major field of social enterprise.

To build a sample including social enterprises for which FT is the main goal and activity, I have worked together with the "Belgian Fair Trade Federation", a network that was created by a number of pioneer FTSEs in 2009. Although this federation was still in the process of its constitution when finishing this article, I used the preliminary list of the members, considering the presence on this peer-recognised list as a sufficient criterion to qualify as an FTSE. On approximately 20 organisations ${ }^{10}$ listed by the Fair Trade Centre and contacted by e-mail, 15 replied positively. This $75 \%$ proportion allows considering the findings, if not totally representative, at least indicative of the trends in the sector. FTSEs in the sample are, moreover, very diverse in their size, number of products, structures and goals. In terms of size, they range from individuals and SMEs with a few employees (e.g. Citizen Dream, Emile, Ethic Store, etc.) to group structures employing one hundred people or so (both Oxfam-MDM and Oxfam-WW). As for the product mixes, they range from a single product type (honey for Miel Maya or wine for Vino Mundo) to a wide range of craft and food products (Oxfam and Fair Trade Organisatie). FTSEs also differ in the types of activities they run. Whereas nearly all FTSEs are involved in the import and distribution of FT products, only a few are also active in regulation and education activities. Such non-commercial activities are mainly run by the pioneer FTSEs such as OxfamMDM, Oxfam-Wereldwinkels or Miel Maya. Legal forms of Belgian FTSEs include charities, co-operatives and commercial companies. To increase the complexity, three FTSEs are composed of both a charity and a co-operative. ${ }^{11}$ The following table synthesizes basic information of the 15 FTSEs.

Table 1: Sample of Belgian FTSEs

\begin{tabular}{|l|c|c|c|c|}
\hline & Legal form & Economic function & Product & Creation \\
\hline Citizen Dream & Business & Import \& retail & Handicraft & 1999 \\
\hline D'ici, d'ailleurs & Charity & Import \& retail & Handicraft & 2005 \\
\hline Emile & Co-operative & Retail & Handicraft & 2004 \\
\hline Ethic Store & Business & Wholesale \& retail & Mixed & 2007 \\
\hline $\begin{array}{l}\text { Fair Trade } \\
\text { Original }\end{array}$ & Charity & Import, wholesale \& retail & Mixed & 1978 \\
\hline Latino & Business & Import \& wholesale & Handicraft & 1998 \\
\hline Max Havelaar & Charity \& co-op & Labelling & Food & 1988 \\
\hline Miel Maya & Charity \& co-op & Import, wholesale \& retail & Honey & 1971 \\
\hline Oxfam-MDM & Charity & Import, wholesale \& retail & Handicraft & 1976 \\
\hline Oxfam-WW & Charity \& co-op & Import, wholesale \& retail & Food & 1975 \\
\hline Satya & Individual & Import \& wholesale & Clothing & 2004 \\
\hline Sjamma & Charity & Import \& retail & Clothing & 1996 \\
\hline $\begin{array}{l}\text { Tout l'or du } \\
\text { monde }\end{array}$ & Co-operative & Retail & Mixed & 2007 \\
\hline
\end{tabular}




\begin{tabular}{|l|c|c|c|c|} 
Vino Mundo & Individual & Retail & Wine & 2004 \\
\hline Weltladen & Charity & Import \& retail & Handicraft & 1978 \\
\hline
\end{tabular}

Compared to much work on governance that focuses on the members of governance structures as the main source of information, our methodology follows Mole's (2003) "alternative" perspective that takes the standpoint of the managers. While the over-reliance on responses by the sole members of the governance structures has been criticised (Cornforth, 2003), the managers' responses are also only partial sources of information. Yet, the more or less external view that some of them have on the governance structures may be useful. The semi-directed interviews included questions on both the role and composition of the governance structures, and other organisational variables such as the legal form, the age, the size, the goals and the resources. Before the interviews, general information was collected on the website of the FTSEs, in organisational documents (presentation leaflets, annual reports, etc.). and in earlier case studies or reports. The interviews were led in 2007 and 2008 and generally lasted between one hour and a half and two hours.

\section{Findings and discussion}

\subsection{Different governance patterns}

The first exercise was to examine the composition of the governance structures of Belgian FTSEs. It is worth noting that the leaders were able to "link" most members of the governance structures to a particular stakeholder category. In other words, these members had a pre-existing relationship with the organisation, and they were thus more than only, for instance, Board members. In several cases, people could be linked to several stakeholder groups simultaneously (e.g., an employee who is also a consumer and a shareholder). The following table presents the major stakeholders involved in the governance of the 15 FTSEs. The order of appearance of the stakeholders is the one associated to their numeric representation on the Board and in the General Assembly. As shown in the last column, the governance models of the Belgian FTSEs can be grouped into three categories, which will be commented further.

Table 2: Stakeholders represented in the governance of the Belgian FTSEs

\begin{tabular}{|c|c|c|c|c|c|}
\hline & $\begin{array}{c}\text { Stake- } \\
\text { holder } 1\end{array}$ & $\begin{array}{c}\text { Stake- } \\
\text { holder } 2\end{array}$ & $\begin{array}{c}\text { Stake- } \\
\text { holder } 3\end{array}$ & $\begin{array}{c}\text { Stake- } \\
\text { holder } 4\end{array}$ & $\begin{array}{c}\text { Type of } \\
\text { governance }\end{array}$ \\
\hline Citizen Dream & Managers & FT partners & $\begin{array}{l}\text { Financial } \\
\text { institution }\end{array}$ & Individuals & Multi-stakeholder \\
\hline D'ici d'ailleurs & Volunteers & & & & Volunteer-based \\
\hline Emile & Managers & Individuals & & & Managerial \\
\hline Ethic Store & Managers & & & & Managerial \\
\hline $\begin{array}{l}\text { Fair Trade } \\
\text { Organisatie }\end{array}$ & Managers & $\begin{array}{c}\text { Mother } \\
\text { organisation }\end{array}$ & & & Managerial \\
\hline Latino & Manager & & & & Managerial \\
\hline Max Havelaar & FT partner & $\begin{array}{c}\text { Financial } \\
\text { institutions }\end{array}$ & $\begin{array}{l}\text { Partner } \\
\text { NGOs }\end{array}$ & Founder & Multi-stakeholder \\
\hline Miel Maya & Volunteers & Partner & & & Multi-stakeholder \\
\hline
\end{tabular}




\begin{tabular}{|l|c|c|c|c|c|} 
& & NGOs & & & \\
\hline Oxfam-MDM & Volunteers & & & & Volunteer-based \\
\hline $\begin{array}{l}\text { Oxfam- } \\
\text { Wereldwinkels }\end{array}$ & Volunteers & Employees & $\begin{array}{c}\text { Partner } \\
\text { NGOs }\end{array}$ & & Multi-stakeholder \\
\hline Satya & Managers & & & & Managerial \\
\hline Sjamma & Volunteers & & & & Volunteer-based \\
\hline $\begin{array}{l}\text { Tout l'or du } \\
\text { monde }\end{array}$ & Managers & $\begin{array}{c}\text { Commercial } \\
\text { partner }\end{array}$ & & & Managerial \\
\hline Vino Mundo & Manager & & & & Managerial \\
\hline Weltladen & Volunteers & & & & Volunteer-based \\
\hline
\end{tabular}

The first group includes FTSEs founded by one or two persons who are in charge of the management as well as the governance functions. Sometimes, a few individuals are associated to the venture, typically friends or family. But in this case, the founders generally keep the control on the decision-making power. In two FTSEs, the Board existed only on the paper. In the other FTSEs, the Board was clearly under the control of the manager. Stakeholders' representation is thus inexistent, or at least very low. This governance pattern corresponds to the "rubber stamp" model identified by Cornforth (2003). The interviews revealed that the entrepreneurs chose this model because they otherwise feared to lose the control on the company or to slow down the decision-making process. This is also why Boards in these FTSEs are very small (most often three persons, corresponding to the minimal legal requirement for companies in Belgium). But the low involvement of external stakeholders and the small role of governance, while leaving much room for manoeuvre to the managers, also limit the development of the FTSE. Indeed, these FTSEs have only few investors and thus little possibility to increase their capital. They also lack the expertise that stakeholders may provide on the different dimensions of the FT activity (see the third category). Other solutions may be found, however, to capture such an expertise. For instance, Satya's manager, having much expertise in terms of product development and producer support but much less in terms of commercial strategy, gathered a few friends from the business world in an "advisory group" that helped her dealing with the commercial issues while keeping the exclusive decision-making power. Finally, the low control on managerial action contrasts with the recommendations of the agency perspective, which would predict persistent inefficiencies, if not to fraudulent behaviours (Fama \& Jensen, 1983; Jensen \& Meckling, 1976).

The second category consists of the volunteer-based FTSEs. In small volunteer-based FTSEs (such as Sjamma or Weltladen), all volunteers automatically become members of the General Assembly, which is conceived as the body through which volunteers are involved. In other, larger FTSEs (typically Oxfam-MDM), a few other stakeholders (such as employees or partner NGOs) are involved beside the volunteers but with a clear dominance of the latter. As volunteers are too numerous to participate all to the governance, each worldshop sends two representatives to the General Assembly. Board members are also elected on a regional basis, so as to ensure the participation of volunteers from different regions. The volunteer-based FTSEs generally have a high participatory nature and advanced democratic decision-making processes, fitting well to the democratic paradigm described by Cornforth (2003). Boards in such FTSEs are much larger than in the other categories (average of thirteen members). The drawback is that the decision-making 
processes may be much slower and heavier, especially in the commercial domain for which most volunteers lack expertise. It is thus no wonder that volunteer-based FTSEs are generally performing well in the socio-political dimensions of FT (such as education and advocacy), but have a lower commercial development.

Finally, a third category is composed of FTSEs with a diversity of stakeholders in their governance structures. These stakeholders may be managers, employees, volunteers, individual shareholders, financial institutions, partner NGOs and FTOs, etc. Two avenues for "multistakeholdership" may be distinguished. The first is embodied by Citizen Dream and Max Havelaar, which had a multi-stakeholder configuration from the beginning. Interviews with the managers and with the Board members representing different stakeholders suggest that the governance model was rather that of "stewardship" than that of "agency". In other words, the various governing stakeholders were rather considered as partners of the managers, bringing their expertise and their resources in the context of a collective venture. However, in the case of Citizen Dream, the focus on stewardship rather than agency, entailing a low control on the managerial action, may be seen as one of the reasons why the Board left the managers make several mistakes that contributed to the ultimate bankruptcy in 2008.

Another avenue for multi-stakeholdership is that of Oxfam-WW and Miel Maya, which have evolved from a volunteer-based charity form to a "group structure" in which the charity remains governed by volunteers while the business entity's governance includes stakeholders with business expertise. In these two cases, however, the charity part holds the majority of the shares in the cooperative, thereby ensuring that the volunteers keep the control over the whole group and "that the commercial activity remains subordinated to the primary social mission"12. However, the coexistence of two governance logics - democracy for the volunteers' representation and expertise for the business-oriented stakeholders - may entail typical tensions between volunteers fearing to lose the control on the economic activity, and managers complaining that participation of volunteers slows down the decision-making in commercial domains (e.g., Cornforth, 2004). One manager asked, for instance: "Is it necessary and useful that volunteers give their advice on every point of the marketing strategy, on every type of packaging?"13 Finally, it is worth noting that, contrarily to British FTSEs such as Cafédirect, Divine Chocolate or Twin, producers are not represented in the governance of Belgian multistakeholder FTSEs. Neither are consumers. However, two interviewees admitted that they were planning to adopt producer ownership schemes in a near future. This illustrates the importance of imitation and, more globally, of institutional influences on the shaping and the evolution of the governance models.

\subsection{What do the differences in governance reflect?}

The managers were asked to comment the reasons behind the composition of the governance structures. Beyond the traditional functions of governance (such as democracy, expertise, control, etc.), the managers emphasised the influence of elements that can be grouped around two issues: the capture of specific resources (in the broad sense) and the formulation of the organisational goals. It is worth noting that these two issues are also emphasised by other authors examining the governance of social enterprises (Campi et al., 2006; Gardin, 2006). 


\section{Governance and resources}

Certain managers, especially in the context of a rather managerial governance model, reported that shareholders and financial institutions had been involved specifically to gain access to financial resources. This was particularly striking in Citizen Dream, where the FTSE obtained access to long-term credit at a regional public investment agency in exchange for a representation of the latter on its Board. Another member of Citizen Dream's Board was Fair Trade Original, which had a commercial relationship with the former. The mutual participation in governance allowed more systematic exchange of knowledge and skills, benefiting both FTSEs. More particularly, Citizen Dream secured its access to certain categories of handicraft products and Fair Trade Original secured their retailing in a dozen of shops. This can be viewed as an example of "co-optation" of stakeholders who can facilitate and secure the access to crucial resources, as described by the resource dependence theory (Pfeffer \& Salancik, 1978):

When asked why external partners, such as other FTSEs and NGOs, had been invited on the Boards of Citizen Dream and Max Havelaar, managers reported a will to involve other organisations whose advice is considered as important for the organisation's strategy. In the case of Max Havelaar, the external NGOs and FTSEs were already involved in the founding of the organisation. Development NGOs in particular have been included on Max Havelaar's Board to provide their experience, their networks of contacts, but also their legitimacy, for instance concerning the relationships with the producers in the South or in the context of education campaigns.

The interviews in volunteer-based FTSEs confirmed that voluntary work was a crucial resource that the managers wished to stimulate through their central representation in governance. For large FTSEs such as Oxfam-MDM and Oxfam-Wereldwinkels, participation of local volunteers to the Board was a manner to communicate concerns of local worldshops to the central organisation. Managers confirmed that, without a representation in the governance bodies, it is likely that volunteers would feel less concerned by the evolution of the organisation and thus that they would be less motivated in their work. Through a presence on the Board, volunteers' representatives can ensure that the organisation's projects and functioning are worth the time they give (typically in the worldshops). They are thus able to confirm the trustworthiness of the organisation towards the broader community of volunteers. ${ }^{14}$

Finally, FTSEs relying on gifts and subsidies (e.g. Max Havelaar and Miel Maya) did not directly involve stakeholder groups providing these resources (i.e., donors and public institutions). However, Boards of both institutions included actors who indirectly facilitated (or even condition) the provision of these resources by increasing the legitimacy to the FTSEs' activities: volunteers in the case of Miel Maya, and external NGOs in the case of Max Havelaar). The presence of these "trustworthy" stakeholders on the Board visibly functioned as a positive signal towards stakeholders willing to provide financial resources, primarily donors and public institutions (Ortmann \& Schlesinger, 1997; Preston \& Brown, 2004).

\section{Governance and organisational goals}


As already mentioned, the presence of particular stakeholders in the governance of social enterprises can be a way for these stakeholders to balance their respective goals in the context of the formulation of the organisational missions and priorities. But linking each stakeholder group to particular organisational goals is difficult, as the stakeholder groups may be very heterogeneous and extend the scope of their interests beyond the reasons of their initial involvement. In the first governance model, it could have been assumed that entrepreneurs, shareholders and financial institutions, being dependent on the financial performance of the FTSE, would be primarily interested in the commercial dimension of the activity. While such an interest was indeed central, several managers of these FTSEs suggested that most of these stakeholders were also particularly concerned about the other dimensions of the FT activity, particularly producer support. Interviews in FTSEs such as Citizen Dream suggested that investors $^{15}$ were interested as much in how the livelihoods of producers were improved than in the economic performance of the organisations. Or, more exactly, they required a level of performance that would safeguard their investment and allow for producer support, but not a turnover that would be made at the expense of the producers. We are thus in a situation in which investors accept to reduce their return on investment or at least to let it be constrained by the social and political goals. Although, theoretically, the pursuit of these non-economic goals may, in turn, increase the economic performance-which is far from systematic in the context of FT-, it is a fact that such a performance is of relatively less importance in FTOs than in traditional companies. Investors, and managers themselves, therefore have an interest in not allowing the social and political dimensions to be overlooked.

The managers of the volunteer-based FTSEs emphasised the contribution of volunteers to the development of producer support and education and advocacy campaigns. If also interested in the commercial dimension, it was rather as a consequence of their social and political preoccupations (e.g. they spend time selling in the "worldshop" in order to help the producers and to educate consumers on the formers' living conditions) than because of their commercial skills, which they often lacked (Le Velly, 2004). Volunteers may also be seen as delegated by citizens and the society in general to ensure that the organisation contributes to the public good (Harrow \& Palmer, 2003). Harrow and Palmer (2003) speak of such a control as "public ownership". But, concretely, citizens are too numerous, too heterogeneous and not organised collectively. When volunteers participate in public good production, they may thus be assumed to represent the citizens or at least to constitute a link between the FTO and the larger society. This dynamics finds an illustration in several volunteer-based FTOs. For instance, in OxfamMDM, volunteers on the Board each represent a larger group of volunteers in a particular region. This group is the most visible part of an even broader community of supporters and customers who are interested in Oxfam's socio-political agenda. This confirms the role of volunteers as "guardians" of the mission (Harrow \& Palmer, 2003). Such a guardian role, however, may also apply to the financial and economic dimensions of FTOs' activities. Indeed, as Harrow and Palmer (2003) observe, volunteers on the Board are increasingly accountable for the financial situation of the organisation. Certain managers of volunteer-based FTSEs, however, complained about the low expertise of volunteers in terms of financial and commercial decision-making. 
This may help to explain why the large Belgian FTSEs that were initially volunteer-based gradually evolved towards involving other stakeholders in their governance, often parallel with an organisational "duplication" in the context of a group structure. Involving diverse stakeholders with specific goals and expertise in the governance structures may lead to or at least reinforce the pursuit of diverse missions, as has been suggested-yet not formally demonstratedin other fields of social enterprise such as work integration (Campi et al., 2006; Defourny \& Nyssens, 2006). The interviews in Oxfam-WW, Max Havelaar, Miel Maya and Citizen Dream suggest that the multiple goals were already present from the founding of the FTSE and that the multi-stakeholder configuration secured the balanced pursuit of these various goals. Max Havelaar's former manager, for instance, explained that gathering stakeholders such as investors, partner NGOs, financial institutions, and volunteers provided a strategic contribution and an expertise for the multiple goals of the FTSE.

The involvement of various stakeholders may, however, lead to tensions. The evolution of the Board of Oxfam-WW offers an interesting illustration. Oxfam-WW started with a Board composed only of volunteers. Economic democracy was clearly the main consideration, reflecting the importance of this value in the early history of FT. In the 1980s, a series of NGOs with whom Oxfam-WW collaborated were invited to provide expertise on how to improve producer support. Some of them became official members of the GA. At that time, thanks to the contribution of these NGOs and the specialisation of certain volunteers in producer support issues, the partner commission formalised its functioning and increased its importance. In the 1994, the cooperative entity was created. People with business experience and skills were hired at all levels, including general management. This brought insights of the business world to the cooperative, including jargon, habits, and communication. The governance of the cooperative, previously exerted only by volunteers and partner NGOs, was progressively opened to people with business skills. In the first place, this happened through a business advisory group. But recently, a direct representation of these experts was decided, although they would not be democratically elected. This led to hostility from certain volunteers, illustrating a tension between the democratic role of governance focusing on representation of the members (the volunteers), and the stewardship model, with Board members supposed to bring expertise and improve the organisation's economic performance.

\section{Conclusion}

The purpose of this article was to use FTSEs to examine some key issues in the study of social enterprise governance, such as Board composition and roles and stakeholder involvement (Cornforth, 2003; 2004; Mason, 2009). The case of Belgium enabled to bring these insights using original empirical material from a country where FTSEs have received little academic attention. Examining a large proportion of the Belgian FTSEs, I distinguished three governance models each entailing different governance paradigms: the managerial model, the volunteerbased model and the multi-stakeholder model. In the first model, governance structures were rather viewed as a "rubber stamp" for managerial decision-making. Other key roles, however, were highlighted based on the contribution of the governing stakeholders to the long-term access to financial resources. Moreover, investors contributed not only to economic goal setting and 
decision-making but also monitored the social (and in some cases political) dimensions of the FT activity.

The representation of volunteers, clearly anchored in a democratic tradition, was also explained in a more strategic sense, both to secure the commitment of the volunteers to the FTSE and to show trustworthiness in front of other stakeholders such as public authorities or donators, more eager to support an organisation whose public benefit was secured by the contribution of volunteers. While the contribution to volunteers to economic decision-making was not absent, it was mainly on the social and political dimensions of FT that managers highlighted their contribution. This was explained not only by the personal motivations of the volunteers, but also by their role of "guardians" of the organisational missions on behalf of the broader society.

The third model was the multi-stakeholder one, which either existed from the founding (Citizen Dream and Max Havelaar) or had gradually emerged from a basically volunteer-based governance (Oxfam-WW and Miel Maya). In both cases, the strategic contribution of the multiple stakeholders to the setting of the multiple goals was emphasized. This allowed FTSEs to capture a multidimensional expertise as well as multiple resources. The presence of various types of stakeholders (volunteers, employees, shareholders, NGOs, etc.), however, was also a source of tensions. The case of Oxfam-WW illustrated the tension between the democratic tradition supported by the volunteers and a more expertise-based, stewardship vision of governance promoted by the managers.

In the three governance models, it was possible to link, to a certain extent, the composition of the governance structures, the access to resources and the goal priorities regarding the different dimensions of the FT activity. In brief, governance appeared as an organisational entry revealing much information about the vision and the strategy of the FTSE. Of course, this study was limited to Belgian FTSEs and based on interviews with the managers. In such sense, it must be considered as a first attempt in characterising the specific features and challenges of organisational governance in the FT context. International comparative studies exploring FTSE's governance in a more longitudinal perspective, combining the standpoints of diverse organisational actors, would be most welcome in the future. As this article has tried to show, the multidimensional nature of FT and the coexistence of different types of FTSEs make this a very interesting field to investigate the challenges of governance in social enterprises. Whatever the field of activity, social enterprises and those researching them should pay more attention to the importance of adopting and conceiving governance schemes that are adapted to their multiple missions and enable the access to multiple resources.

\section{References}

Becchetti, L. \& Rosati, F. C. (2005), The demand for socially responsible products: empirical evidence from a pilot study on fair trade consumers, Society for the Study of Economic Inequality, Palma de Mallorca.

Campi, S., Defourny, J. \& Grégoire, O. (2006), "Work integration social enterprises: are they multiplegoal and multi-stakeholder organizations?", in M. Nyssens (Ed.), Social Enterprise. At the crossroads of market, public policies and civil society., Routledge, London. 
Cornforth, C. (2003), "Introduction: the changing context of governance - emerging issues and paradoxes", in C. Cornforth (Ed.), The Governance of Public and Non-Profit Organisations. What do boards do?, Routledge, London \& New York.

Cornforth, C. (2004), "The Governance of Cooperatives and Mutual Associations: a Paradox Perspective", Annals of Public and Cooperative Economics, 75:1, 11-32.

Davies, I. A. \& Crane, A. (2003), "Ethical Decision Making in Fair Trade Companies", Journal of Business Ethics, 45, 79-92.

Defourny, J. \& Nyssens, M. (2006), "Defining social enterprise", in M. Nyssens (Ed.), Social Enterprise. At the crossroads of market, public policies and civil society, Routledge, London, 3-26.

Defourny, J. \& Nyssens, M. (2008), "Conceptions of Social Enterprise in Europe and in the United States. A Comparative Analysis", 8th ISTR International Conference and 2nd EMES-ISTR European Conference: "The Third Sector and Sustainable Social Change: New Frontiers for Research", Barcelona.

Diaz Pedregal, V. (2007), Le commerce équitable dans la France contemporaine. Idéologies et pratiques, L'Harmattan, Paris.

Doherty, B. \& Tranchell, S. (2007), "“'Radical mainstreaming” of fairtrade: the case of The Day Chocolate Company", Equal Opportunities International, 26:7, 693-711.

Donaldson, T. \& Preston, L. E. (1995), "The Stakeholder Theory of the Corporation: Concepts, Evidence, and Implications", The Academy of Management Review, 20:1, 65-91.

Fama, E. F. \& Jensen, M. C. (1983), "Separation of Ownership and Control", Journal of Law \& Economics, 26:2, 301-325.

Freeman, R. E. (1984), Strategic management: A stakeholder approach, Pitman, Boston.

Gardin, L. (2006), "A variety of resource mixes inside social enterprises”, in M. Nyssens (Ed.), Social Enterprise. At the crossroads of market, public policies and civil society, Routledge, London, 111-136.

Gendron, C. (2004), Un nouveau mouvement socio-économique au coeur d'une autre mondialisation: le commerce équitable, Comparaisons Internationales, Chaire de Recherche en Développement des Collectivités (Université du Québec en Outaouais), Ottawa.

Harrow, J. \& Palmer, P. (2003), "The Financial Role of Charity Boards", in C. Cornforth (Ed.), The Governance of Public and Non-Profit Organisations. What do boards do?, Routledge, London \& New York.

Hervieux, C. (2008), Les enjeux de l'entrepreneurship social : le cas de Cooperative Coffees, une entreprise de commerce équitable au Nord, Cahier de la Chaire de responsabilité sociale et de développement durable, Montréal.

Huybrechts, B. (2009), Explaining Organisational Diversity in Fair Trade Social Enterprises, University of Liège, HEC Management School, PhD in Management Sciences.

Huybrechts, B. \& Defourny, J. (2008), “Are Fair Trade Organizations necessarily Social Enterprises?", Social Enterprise Journal, 4:3, 186-201.

Jensen, M. C. \& Meckling, W. (1976), "Theory of the firm: Managerial behaviour, agency costs and ownership structure", Journal of Financial Economics, 3, 305-360.

Krier, J.-M. (2005), Fair Trade in Europe 2005: facts and figures on Fair Trade in 25 European countries, Brussels.

Labie, M. (2005), "Economie sociale, tiers secteur, non-profit : à la recherche d'un cadre de gouvernance adéquat", in A. Finet (Ed.), Gouvernement d'entreprise. Enjeux managériaux, comptables et financiers, De Boeck, Bruxelles, 101-124.

Le Velly, R. (2004), Sociologie du marché. Le commerce équitable : des échanges marchands contre le marché et dans le marché, Université de Nantes, Sociologie, 328.

Martin, R. L. \& Osberg, S. (2007), "Social Entrepreneurship: The Case for Definition", Stanford Social Innovation Review, Spring 2007, 29-39.

Mason, C. (2009), "Governance and SEs", in B. Doherty, G. Foster, C. Mason, J. Meehan, K. Meehan, N. Rotheroe \& M. Royce (Eds.), Management for Social Enterprises, SAGE Publications, London.

Moore, G. (2004), "The Fair Trade movement: parameters, issues and future research", Journal of Business Ethics, 53:1, 73-86.

Moore, G., Slack, R. \& Gibbon, J. (forthcoming), "Criteria for Responsible Business Practice in SMEs. An exploratory case of U.K. Fair Trade Organisations", Journal of Business Ethics. 
Nicholls, A. (Ed.) (2006), Social Entrepreneurship. New Models of Sustainable Social Change, Oxford University Press, Oxford.

Nicholls, A. (forthcoming), "Fair Trade in the UK: Towards an Economics of Virtue", Journal of Business Ethics.

Nicholls, A. \& Opal, C. (2005), Fair Trade. Market-driven Ethical Consumption, Sage Publications, London.

Ortmann, A. \& Schlesinger, M. (1997), "Trust, repute and the role of non-profit enterprise", Voluntas, $8: 2,97-119$.

Peattie, K. \& Morley, A. (2008), "Eight paradoxes of the social enterprise research agenda", Social Enterprise Journal, 4:2, 91-107.

Pfeffer, J. \& Salancik, G. (1978), The External Control of Organizations: A Resource Dependence Perspective, Harper \& Row, New York.

Preston, J. B. \& Brown, W. A. (2004), "Commitment and performance of charity board members", Charity Management \& Leadership, 15:2, 221-238.

Raynolds, L. T. \& Wilkinson, J. (2007), "Fair Trade in the agriculture and food sector", in L. T. Raynolds, D. L. Murray \& J. Wilkinson (Eds.), Fair Trade. The Challenges of Transforming Globalization, Routledge, London.

Reed, D., Thomson, B., Hussey, I. \& Lemay, J.-F. (forthcoming), "Fair Trade in Canada: Towards a Research Agenda ", Journal of Business Ethics.

Tallontire, A. (2000), "Partnerships in Fairtrade: Reflections from a Case Study of Cafédirect", Development in Practice, 10:2, 166-177.

Viganò, E., Glorio, M. \& Villa, A. (2008), Tutti i numeri dell'equo. Il commercio equo e solidale in Italia, Edizioni dell'Asino.

Wilkinson, J. (2007), "Fair Trade: Dynamic and Dilemmas of a Market Oriented Global Social Movement", Journal of Consumer Policy, 30:3, 219-239.

\footnotetext{
${ }^{1} 30$ to $40 \%$ annual growth for products labelled by Fair Trade Labelling Organisations International according to its latest annual reports (FLO, 2002, 2005, 2007 \& 2008). Fair Trade sales reached $\$ 900$ million worldwide in 2003 (Nicholls \& Opal, 2005), and \$660 million in Europe in 2004 (Krier, 20005); market shares range from 1 or $2 \%$ for several products up to $20 \%$ for roasted coffee in the UK and even $50 \%$ for banana in Switzerland (Krier, 2005).

${ }^{2}$ In the literature about Fair Trade and, more generally, development, the terms "North" and "South" refer to the geopolitical division of the world between, respectively, "developed" and "developing" countries.

${ }^{3}$ This excludes many supermarkets and wholesalers for which Fair Trade represents only a part of their activity. The inclusion of these mainstream players would probably yield interesting information, but this lies beyond the scope of this study.

${ }^{4}$ FINE is an informal network gathering the four main Fair Trade umbrella organs: EFTA (European Fair Trade Association), NEWS (Network European Worldshops), FLO (Fairtrade Labelling Organisations International) and IFAT (International Fair Trade Association).

${ }^{5}$ International Fair Trade Association, formerly International Federation for Alternative Trade

${ }^{6}$ Fairtrade Labelling Organisations International

${ }^{7}$ European Fair Trade Association

8 http://www.wfto.com/index.php?option=com content\&task=view\&id=153\&Itemid=186\&lang=en, viewed on September 13, 2009. This excludes the organisations and networks that are only engaged in promoting and advocating for FT from the scope of this study. I will consider these structures as major stakeholders of FTOs, but not as FTOs themselves.

${ }^{9}$ In 2007, the average consumption exceeded 7 euros per capita per year (Huybrechts, 2009). Awareness of the FT concept reached $84 \%$ of the population according to the 2008 survey led by the Trade for Development Centre.

${ }^{10}$ It is difficult to give a precise number because of the instability of the sector. Indeed, during the study, many new FTSEs have been launched. On the other side, two FTSEs in the sample have gone bankrupt just after the study.

${ }^{11}$ Although the charity and the co-operative parts of these organisations are legally autonomous, their strategy and governance are commonly organised. These groups can thus be considered as single organisations.

${ }_{12}$ A manager of a group structure; original quotation in Dutch, author's translation.

${ }^{13}$ A manager of a group structure; original quotation in Dutch, author's translation.

${ }^{14}$ In the same way as what is described for donors sitting on the Board of Directors (e.g. Hansmann, 1996).
} 
${ }^{15}$ Without overlooking the heterogeneity of these investors, our description is based on the comments of two managers, one shareholders and one franchisee of Citizen Dream, as well as on the interviews with managers of similar FTOs in the sample (e.g. Signaléthique, Ethic Store, Saldac, etc.). 